Original

\title{
A COX-2 Inhibitor, SC58125, Promotes Liver Carcinogenesis in a Rat Medium-Term Liver Bioassay, Possibly due to Induction of CYP 2B1 and 3A1
}

\author{
Masanao Yokohira ${ }^{1,2}$, Hijiri Takeuchi ${ }^{1,2}$, Keiko Yamakawa ${ }^{1}$, \\ Kousuke Saoo $^{1}$, Yoko Matsuda ${ }^{1}$, Yu Zeng ${ }^{1}$, Kyoko Hosokawa ${ }^{1}$, \\ Hajime Maeta ${ }^{2}$, and Katsumi Imaida ${ }^{1}$ \\ ${ }^{1}$ Onco-Pathology, Department of Pathology and Host-Defence, Faculty of Medicine, Kagawa University, 1750-1 \\ Ikenobe, Miki-cho, Kita-gun, Kagawa 761-0793, Japan \\ 2 st Department of Surgery, Faculty of Medicine, Kagawa University, 1750-1 Ikenobe, Miki-cho, Kita-gun, Kagawa \\ 761-0793, Japan
}

\begin{abstract}
Epidemiological studies have shown a significant inverse association between intake of COX inhibitors and the risk of colorectal cancer. The present study was conducted to determine whether SC560 (a COX-1 selective inhibitor), NS398 (COX-2 selective), SC58125 (COX-2 selective), nimesulide (COX-2 selective) and indomethacin (COX non selective), might exert chemopreventive influence on diethylnitrosamine (DEN) initiated hepatocarcinogenesis in a medium-term liver carcinogenesis bioassay in F344 male rats. Contrary to expectation, in the SC58125 treated group, the numbers and areas of glutathione S-transferase placental form (GST-P) positive liver cell foci were increased significantly, along with liver weights. In the other groups no significant changes were evident. Histopathologically, liver cells of SC58125 treated rats showed hypertrophy similar to cases with phenobarbital treatment. For further clarification, Experiment 2 was performed. After 2 weeks on test chemicals and basal diet, animals underwent histopathological, microarray and quantitative RT-PCR assessment. CYP 2B1 and 3A1 were found to be induced, again similar to phenobarbital cases. Although COX-2 selective inhibitors are clearly good candidates for chemoprevention, it is necessary to examine them carefully for any adverse toxic effects at the whole body level before considering their application as chemopreventive agents. (J Toxicol Pathol 2006; 19: 37-45)
\end{abstract}

Key words: COX, liver, carcinogenesis, CYP, GST-P

\section{Introduction}

Non-steroidal anti-inflammatory drugs (NSAIDs) are the most widely used therapeutic agents for treatment and several epidemiological studies have shown a significant inverse association between the intake of aspirin and the risk of colorectal cancer ${ }^{1,2}$. The mechanisms by which traditional NSAIDs act to reduce the risk of colon carcinogenesis are considered to primarily involve the inhibition of arachidonic acid metabolism via cyclooxygenase (COX) enzymes, which, in turn, modulates the synthesis of prostaglandins (PGs) that affect cell proliferation, tumor growth, and immune responsiveness ${ }^{3,4}$.

The two COX isozymes, COX-1 and COX-2, have only

Received: 7 November 2005, Accepted: 1 January 2006 Mailing address: Katsumi Imaida, Onco-Pathology, Department of Pathology and Host-Defense, Kagawa Medical University, 1750-1 Ikenobe, Miki-cho, Kita-gun, Kagawa 761-0793, Japan

TEL: 81-891-2109 FAX: 81-87-891-2112

E-mail: imaida@med.kagawa-u.ac.jp $\sim 60 \%$ homology, but their active site residues are almost entirely preserved. In contrast to COX-1, a constitutively expressed housekeeping gene contributing to normal physiological functions in the majority of tissues, COX-2 is an inducible immediate early gene which has recently been postulated to be involved not only in inflammation but also in carcinogenesis, impacting on cell proliferation, differentiation, apoptosis, angiogenesis, metastasis and immunological surveillance ${ }^{5-7}$. However, there have been only a few studies which have examined the chemopreventive effects of COX-2 inhibitors together with their chemopreventive effects on the liver in the same experiment ${ }^{8,9}$.

The aim of the present study was to investigate the influence of several COX inhibitors on liver carcinogenesis. SC560 (COX-1 selective), NS398, SC58125 and nimesulide (COX-2 selective) and indomethacin (COX non-selective inhibitor) were selected for this experiment. The dose of chemicals in the basal diet was decided as $10 \mathrm{ppm}$ in consideration of the maximum possible dose of daily human intake as a prescribed medicine in Japan. The effects of the 
COX inhibitors were examined on diethylnitrosamine (DEN) initiated hepatocarcinogenesis in a medium-term liver carcinogenesis bioassay in F344 male rats based on the two stage concept of carcinogenesis ${ }^{10-12}$ with the potential to focus on initiating ${ }^{13,14}$ or promoting activity ${ }^{15,16}$. Glutathione S-transferase placental form (GST-P) positive foci, which can be readily detected by immunohistochemistry, are established preneoplastic lesions used as end-points for assessing modification potential. This bioassay is used for investigating the modification of chemicals in the liver and has also provided information concerning inhibitory potential including chemopreventive agents ${ }^{17}$. Therefore, the modifying potentials of the selected COX inhibitors on hepatocarcinogenesis were investigated by this bioassay in this study.

A DNA microarray study was performed to clarify the cause of GST-P positive foci modification by test chemicals and the results of DNA microarray were confirmed by quantitative real time RT-PCR.

\section{Materials and Methods}

\section{Chemicals}

SC560 (lot 70340), NS398 (lot 70590), SC58125 (lot 70655), nimesulide (lot 70640) and indomethacin (lot 70270) were purchased from Cayman Chemical (Michigan, USA); detailed information about these chemicals is provided in Table 1. DEN was purchased from Tokyo Kasei
Kogyo Co., Ltd. (Tokyo, Japan) and phenobarbital (lot 16211602) from Wako Pure Chemical Industries, Ltd. (Osaka, Japan).

\section{Animals}

The animals were housed in an air-conditioned room at a temperature of $22 \pm 1^{\circ} \mathrm{C}$ and a relative humidity of $60 \pm$ $10 \%$, with a $12 \mathrm{~h}$ light/dark cycle, and maintained on a basal pellet diet (Oriental MF, Oriental Yeast Co., Tokyo, Japan) and tap water ad libitum. They were used after a two-week acclimation period for the experiment. The study was conducted in accordance with the Japanese laws and related operation rules on the treatment and use of laboratory animals at Kagawa University, Faculty of Medicine.

\section{Treatment of animals}

Experiment 1: The experimental protocol for the medium-term liver bioassay is shown in Fig. $1^{18}$. A total of 93, 4-week-old, male F344/DuCrj rats were obtained from Charles River Japan Inc. (Atsugi, Japan) and divided into six groups, with 18 rats in group 6 and 15 in each of the other groups. All were given a single intraperitoneal injection of DEN (200 mg/kg body weight) dissolved in $0.9 \% \mathrm{NaCl}$ solution to initiate hepatocarcinogenesis on the first day of the experiment. After 2 weeks on basal diet, they were then administered basal diet containing SC560, NS398, SC58125, nimesulide, or indomethacin at doses of $10 \mathrm{ppm}$ or $0 \mathrm{ppm}$ (controls) for the following 6 weeks. The dose of 10

Table 1. Details of Test Chemicals

\begin{tabular}{|c|c|c|c|c|}
\hline \multicolumn{2}{|c|}{ Chemicals } & \multirow[b]{2}{*}{ Structure } & \multirow[b]{2}{*}{ CAS-No. ${ }^{1}$} & \multirow[b]{2}{*}{ IC50 values ${ }^{2}$} \\
\hline Product name & Trivial name & & & \\
\hline \multicolumn{5}{|c|}{$\begin{array}{l}\text { 5-(4-chlorobenzoyl)-1-(4- } \\
\text { methoxyphenyl)-3- } \\
\text { (trifluoromethyl)-1Hpyrazole }\end{array}$} \\
\hline \multicolumn{5}{|c|}{$\begin{array}{l}N-[2-(\text { cyclohexyloxy)-4- } \\
\text { nitrophe nyl]- } \\
\text { methanesulfonamide }\end{array}$} \\
\hline \multicolumn{5}{|c|}{$\begin{array}{l}\text { 5-(4-fluorophenyl)-1-[4- } \\
\text { (methylsulfonyl) phenyl]-3- } \\
\text { (trifluoromethyl)-1Hpyrazole }\end{array}$} \\
\hline $\begin{array}{l}\text { Nimesulide } \\
\quad N-(4-n i \\
\text { methan }\end{array}$ & $\begin{array}{l}\text { 2-phenoxyphe } \\
\text { lfonamide }\end{array}$ & & COX-2 selective inhibitor $51803-78-2$ & $70 \mu \mathrm{M} / 1.27 \mu \mathrm{M}(\mathrm{COX}-1 / \mathrm{COX}-2)$ \\
\hline $\begin{array}{r}\text { Indomethacin } \\
\text { 1-(4-ch } \\
\text { methox } \\
\text { 3-acetic }\end{array}$ & $\begin{array}{l}\text { benzoyl)-5- } \\
\text {-methyl-1Hin } \\
\text { id }\end{array}$ & & COX-1,2 inhibitor $53-86-1$ & $9 \mathrm{nM} / 6.3 \mu \mathrm{M}(\mathrm{COX}-1 / \mathrm{COX}-2)$ \\
\hline
\end{tabular}

1: Chemical Abstracts Service Registry Number.

2: $50 \%$ inhibitory concentration values. 


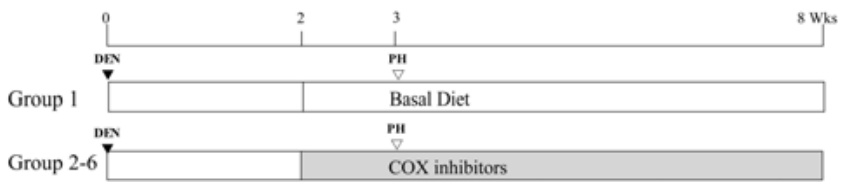

Fig. 1. Experimental protocol of Experiment 1.

Animals: F344/Ducrj, Male rats, 6 weeks old.

Test chemicals: Group 2; COX-1 inhibitor, SC560, 10 ppm in diet, Group 3; COX-2 inhibitor, NS398, 10 ppm in diet, Group 4; COX-2 inhibitor, SC58125, 10 ppm in diet, Group 5; COX-2 inhibitor, nimesulide, 10 ppm in diet, Group 6; COX-1,2 inhibitor, indomethacin, 10 ppm in diet, DEN: Diethylnitrosamine (DEN), $200 \mathrm{mg} / 2 \mathrm{ml}$ saline/kg b.w., intraperitoneal injection. PH: 2/3 Partial Hepatectomy.

ppm was decided since it is almost the same as the upper dose limit of NSAIDs for human daily intake, clinically in Japan. All rats were subjected to two-thirds partial hepatectomy at the end of week 3. Body weights and food consumptions were recorded every two weeks and all surviving rats were sacrificed under ether anesthesia at the end of week 8 of the experiment.

Several rats died after partial hepatectomy, so only 79 rats were included in the final analysis. The general condition of the rats in all groups demonstrated no remarkable change due to any test compound administration during the experimental period.

Experiment 2: For investigation of mRNA expression in the liver induced by SC58125, a total of 40, 4-week-old, male F344/Jcl rats were obtained from CLEA Japan Inc. (Tokyo, Japan) and divided into eight groups of 5 rats each. There were administered basal diet containing $10 \mathrm{ppm}, 5$ ppm or $1 \mathrm{ppm} \mathrm{SC58125,600} \mathrm{ppm} \mathrm{or} 10$ ppm nimesulide ${ }^{8}, 10$ ppm indomethacin, $500 \mathrm{ppm}$ phenobarbital ${ }^{19}$ or basal diet without supplement for 2 weeks. All rats were then sacrificed under ether anesthesia.

\section{Tissue processing}

In Experiment 1, livers were immediately excised at autopsy, weighed and fixed in $10 \%$ neutral buffered formalin. The kidneys on both sides were also excised and fixed at the same time. After $48 \mathrm{~h}$ fixation, livers were cut into 2-3 $\mathrm{mm}$ thick slices, one each from the right and left caudate lobes and two from the right anterior lobe, and embedded with slices of kidney in paraffin for histopathological examination of hematoxylin and eosin stained sections, and immunohistochemical staining for GST-P.

In Experiment 2, livers were immediately excised and divided into three, one portion fixed in $10 \%$ neutral buffered formalin and embedded in paraffin for histopathological examination and the other two frozen immediately in liquid nitrogen for subsequent mRNA analysis.

\section{Immunohistochemistry}

To determine the location of GST-P binding in the livers from Experiment 1, immunohistochemical staining was performed using the VENTANA HX system (VENTANA, Yokohama, Japan). Sections were treated with rabbit anti-rat GST-P antibody (MBL, Nagoya, Japan, $1: 2000)$ and then sequentially with secondary antibody and avidin-biotin complex (ABC). The numbers and areas of GST-P positive foci larger than $0.2 \mathrm{~mm}$ in diameter and the total areas of the liver were measured using an Image Processor for Analytical Pathology (IPAP-WIN, Sumika Technoservice Co., Osaka, Japan $)^{20}$, and the numbers and areas of foci $/ \mathrm{cm}^{2}$ of liver section were then calculated.

\section{RNA isolation}

Total RNA was isolated from liver tissues collected in experiment 2 using the RNAlater RNA Stabilization Reagent (Qiagen Corp., Hilden, Germany) and RNeasy Midi Kit (Qiagen Corp.) was used to collect RNA for DNA microarrays from 4 rats each of the SC-58125 $10 \mathrm{ppm}$, indomethacin $10 \mathrm{ppm}$, phenobarbital $500 \mathrm{ppm}$ and basal diet treated groups. The RNeasy Mini kit was used to collect RNA for quantitative real-time reverse transcriptasepolymerase chain reaction (RT-PCR) of samples from all rats in Experiment 2. The concentration of RNA was measured by optical absorbance at $260 \mathrm{~nm}$.

\section{PamChip ${ }^{\circledR}$ microarrays}

For the customized PamChip ${ }^{\circledR}$ microarray, RatTox. Ver. 1 provided by Olympus, 13 cytochrome P450s and 7 glutathione S-transferases, NADPH, NAT2 and PCNA were chosen, along with GAPDH, cyclophilin and $\beta$-actin genes spotted as internal controls. All genes were spotted in duplicate with oligonucleotide DNA probes $(60 \mathrm{mer})^{21}$. For sample preparation of fluorochrome-labeled cDNA, $15 \mu \mathrm{g}$ aliquots of total RNAs were used, and reverse transcriptase and fluoresceinisothiocyanate isomer (FITC) labeling reactions were performed according to the manufacturer's instructions (LabeloStar Array Kit; Qiagen Corp., Lot 28902, Hilden, Germany). Samples were denatured at $95^{\circ} \mathrm{C}$ for $5 \mathrm{~min}$ and $50 \mu \mathrm{L}$ of hybridization solution containing $5 \times$ SSPE was applied on each test site of the PamChip ${ }^{\circledR}$ microarray. Hybridization was performed with the $3 \mathrm{D}$ microarray system (FD10; Olympus) at $50^{\circ} \mathrm{C}$ with 150 cycles at a rate of $5 \mu \mathrm{L} / \mathrm{s}$, and then each test-site was washed with $50 \mu \mathrm{L}$ of $5 \times$ SSPE 3 times. After the washing, fluorescence images were captured automatically by a cooled $\mathrm{CCD}^{21}$. Signals after each treatment were converted to expression ratios relative to the control using the gene expression analysis software integrated in FD10. Normalization was conducted for each gene against $\mathrm{GAPDH}^{21}$.

\section{Quantitative real-time $R T-P C R$}

First strand cDNA was synthesized from $400 \mathrm{ng}$ of total RNA using TaqMan Reverse Transcription Reagents (Applied Biosystems, CA, USA) according to the manufacturer's instructions. The TaqMan Rodent glyceraldehyde-3-phosphate dehydrogenase (GAPDH) Control Reagent (Applied Biosystems, CA, USA) was used 
for PCR of GAPDH mRNA as an internal control. The mRNA sequences of the rat cytochrome P450 (CYP) 2B1 and CYP3A1 were obtained from Burczynski's report ${ }^{22}$. The primers for CYP2B1 were as follows: forward, 5'CTCCAAAAACCTCCAGGAAATCCTC-3'; reverse, 5'GTGGATAACTGCATCAGTGTATGGC-3'. For CYP3A1 they were: forward, 5'GAGGAGTAATTTGCTGACAGACCTGC-3'; reverse, 5'CCAGGAATCCCCTGTTTCTTGAA-3'. The primers and TaqMan probe for rat proliferating cell nuclear antigen (PCNA) mRNAs were as follows: forward, 5'GCTATGGCTTTCTGTTGCTCATG-3'; reverse, 5'ATCACCCGATCAATCTCCTCAT-3'; and probe, 5'TTGAGGCCAAGGTC-3'.

Amplification was carried out in 96-well plates with a $50 \mu \mathrm{L}$ reaction volume containing $25 \mu \mathrm{L}$ SYBR ${ }^{\circledR}$ Premix Ex Taq $^{\text {TM }}$ (Takara Bio Inc., Otsu, Japan), 200 nM each (GAPDH: $100 \mathrm{nM}$ ) of forward and reverse primers and $50 \mathrm{ng}$ of cDNA. TaqMan probing for rat PCNA was carried out in $50 \mu \mathrm{L}$ reaction mixtures containing $25 \mu \mathrm{L}$ of $2 \times$ TaqMan Universal PCR Master Mix, 50 ng of cDNA, $900 \mathrm{nM}$ of each primer, and $250 \mathrm{nM}$ of TaqMan probe. Quantitative realtime RT-PCR was performed with an ABI PRISM 7000 Sequence Detection System. Cycling conditions were as follows: CYP $2 \mathrm{~B} 1$ and $3 \mathrm{~A} 1,10 \mathrm{~s}$ at $95^{\circ} \mathrm{C}$ and then 45 cycles of $31 \mathrm{~s}$ at $66^{\circ} \mathrm{C}$ followed by $10 \mathrm{~s}$ at $95^{\circ} \mathrm{C}$; PCNA, $2 \mathrm{~min}$ at $50^{\circ} \mathrm{C}, 10 \mathrm{~min}$ at $95^{\circ} \mathrm{C}$ and then 40 cycles of $15 \mathrm{~s}$ at $95^{\circ} \mathrm{C}$ followed by $1 \mathrm{~min}$ at $60^{\circ} \mathrm{C}$. PCR amplification of GAPDH mRNA was similarly carried out. PCR products were detected as increases in fluorescence from cycle to cycle and amplification plots were used to determine the threshold cycle $(\mathrm{Ct})$ at which an increase in reported fluorescence $(\Delta \mathrm{Rn})$ above the line of the optimal value was first detected. The initial copy number of the target mRNA was calculated by plotting the $\mathrm{Ct}$ against the input target quantity. Both the precise amount and quality of total RNA are difficult to assess and therefore we also quantified transcripts of GAPDH gene as an internal control by quantitative RT-PCR. Normalization of the data was achieved by quantitating the cycle number at an arbitrary fluorescence intensity in the linear exponential phase and calculating the ratio of the cycle number of each enzyme relative to that of GAPDH.

\section{Statistical analysis}

Inter-group differences in body weights, organ weights and GST-P positive liver foci numbers or areas $/ \mathrm{cm}^{2}$ were assessed using analysis of variance (post-hoc test). When positive results were obtained, Dunnett's multiple comparison test was conducted to evaluate the statistical significance between treatment groups. $P$ values less than 0.05 were considered significant.

Data for final body weights were analyzed by the Student's t-test. Dose dependence of the promoting effects of SC-58125 was assessed with the Spearman's rank correlation coefficient. Rat CYP 2B1, 3A1 and PCNA mRNA levels were analyzed by the Kruskal-Wallis test.

\section{Results}

\section{Experiment 1}

Body and organ weight and food consumption: Body and liver weights are shown in Table 2. There were no significant changes in body weights but liver weights of group 3 (SC-58125) were increased. These results indicate that SC58125 may have liver toxicity and subsequently proliferate liver cells, or that it may have tumor promoting potential. Kidney weights and food consumption showed no significant variation among the groups (data not shown). These data indicate there are no toxic effect in the kidney and whole body.

GST-P positive foci analysis: Numbers and areas of GST-P positive foci / total liver area per 1 slide are also shown in Fig. 2A and 2B. Compared with the control, the NS398, nimesulide and indomethacin treated groups showed a tendency to decrease. Unexpectedly, the value for group 3 (SC58125) was significantly increased as compared with the control group. Furthermore, the number of GST-P positive foci of SC58125 group was twice than that of basal diet group.

Histopathological changes: To examine the causes of GST-P positive foci increase in the SC58125 treated group, histopathological changes were investigated. SC58125 treated liver cells showed deep stain of the nucleus, vacuole formation and enlarged cells (Fig. 3A, 3B). Some hepatocytes both inside foci as well as in the surrounding parenchyma in the SC58125 treatment group were

Table 2. Effect of COX Inhibitors on Body Weight, Liver and GST-P Positive Foci (Experiment 1)

\begin{tabular}{llcccc}
\hline \multirow{2}{*}{ Groups } & Test chemicals & No.of rats & \multicolumn{3}{c}{ Liver weights } \\
\cline { 3 - 5 } & & & Body weights & Absolute (g) & Relative (\% B.W.) \\
\hline 1 & Basal diet & 16 & $254.55 \pm 15.94$ & $7.69 \pm 0.59$ & $3.02 \pm 0.17$ \\
2 & SC560 & 13 & $251.03 \pm 12.19$ & $7.97 \pm 0.59$ & $3.18 \pm 0.30$ \\
3 & NS398 & 14 & $254.38 \pm 8.80$ & $7.94 \pm 0.41$ & $3.12 \pm 0.17$ \\
4 & SC58125 & 13 & $245.62 \pm 9.39$ & $9.65 \pm 0.59 * * *$ & $3.93 \pm 0.22^{* * *}$ \\
5 & Nimesulide & 12 & $249.53 \pm 9.78$ & $7.77 \pm 0.53$ & $3.11 \pm 0.17$ \\
6 & Indomethacin & 11 & $259.10 \pm 7.13$ & $8.14 \pm 0.51$ & $3.14 \pm 0.22$ \\
\hline
\end{tabular}

* $\mathrm{P}<0.05$ vs. group 6

$* * * \mathrm{P}<0.0001$ vs. group 6. 


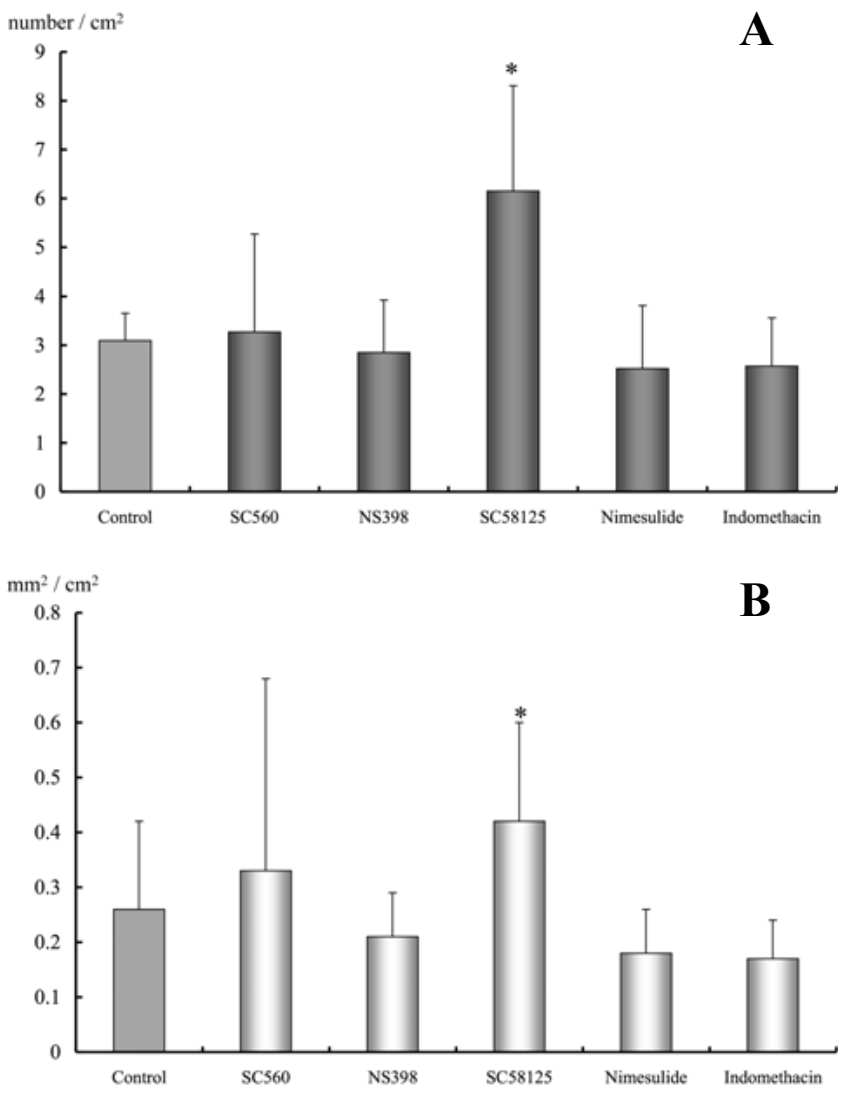

Fig. 2. 2A: Analysis of liver GST-P positive foci (number $/ \mathrm{cm}^{2}$ ). $* \mathrm{P}<0.05$ vs. control group. 2B: Analysis of liver GST-P positive foci $\left(\mathrm{mm}^{2} / \mathrm{cm}^{2}\right)$. $* \mathrm{P}<0.05$ vs. control group.

hypertrophic compared with the control group. This finding was particularly the case in centrilobular areas, as is typically seen in phenobarbital treated livers ${ }^{23}$.

\section{Experiment 2}

From the result of Experiment 1, it was expected that GST-P positive foci were increased by SC58125 by a mechanism similar to that of phenobarbital, via induction of CYPs. In Experiment 2, phenobarbital was used as a positive control.

Expression of mRNAs as assessed with PamChip ${ }^{\circledR}$ microarrays: Data for mRNA expression of the genes chosen for analysis are shown in Table 3, with ratios vs. basal diet treated group rats. Values for CYPs 2B1, 3A1 and 3A2 from SC58125 treated rats were increased as in phenobarbital treated rats, although the degree of alteration was largely different. Increasing values of CYPs $2 \mathrm{~B} 1$ and $3 \mathrm{~A} 1$ in microarrays in this experiment have also been noted in other reports ${ }^{24-26}$ as typical CYP subtypes induced by phenobarbital. In this experiment the CYPs were investigated by quantitative real time RT-PCR.

In the SC58125 and phenobarbital treated groups, values for PCNA seemed to increase vs. control, but this contradicted the microarray data. On account of this unexpected result, we confirmed the expression of PCNA
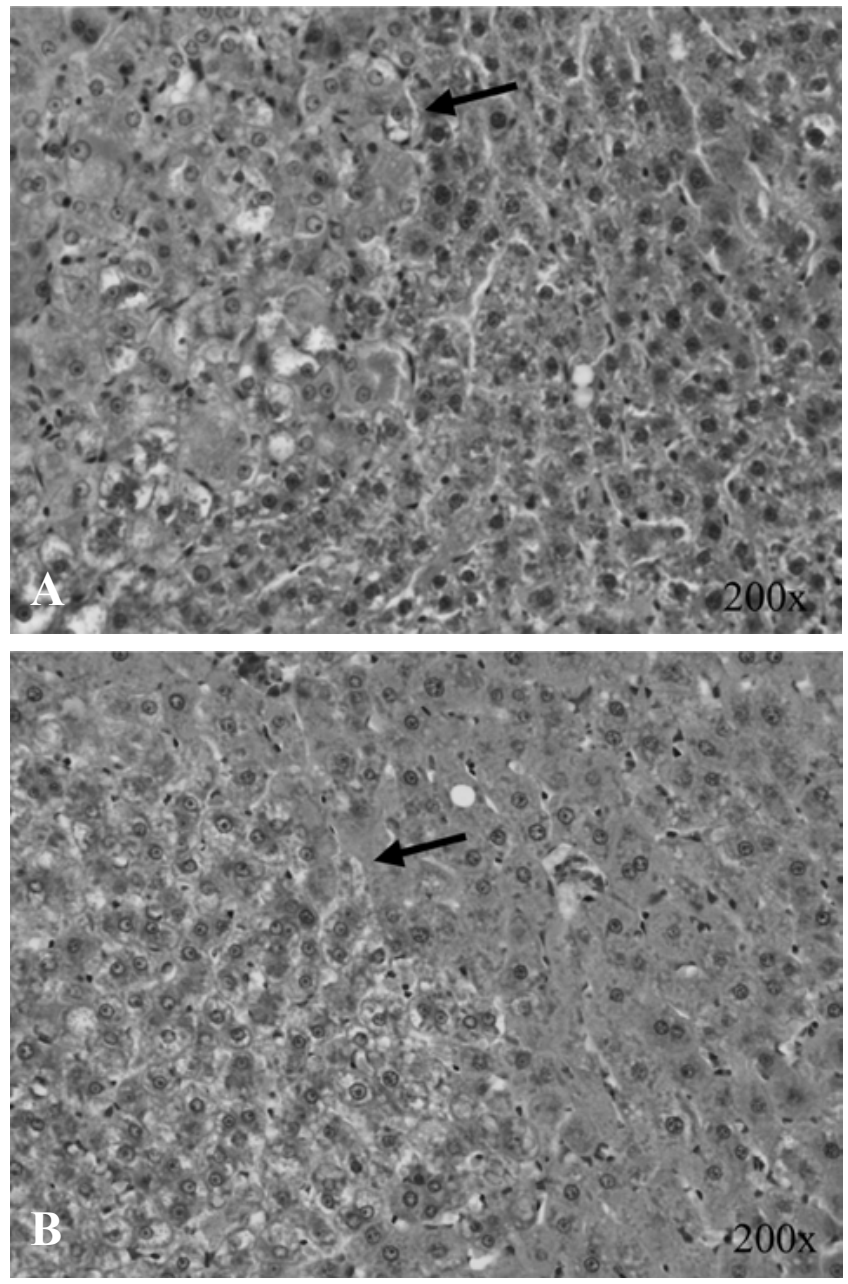

Fig. 3. 3A: Typical histopathological changes of basal diet treated rat livers (control). Arrows indicate foci. SC58125 treated liver cells show deep stain of the nucleus, vacuole formation and enlarged cells. Some hepatocytes both inside foci as well as in the surrounding parenchyma in the SC58125 treatment group were hypertrophic compared with the control group. 3B: Typical histopathological changes of SC58125 treated rat livers. Arrows indicate foci.

mRNA level by quantitative real time RT-PCR.

Quantitative real-time RT-PCR: Ratios of CYP 2B1, 3A1 and PCNA are shown in Fig. 3A, 3B and 3C. With CYP $2 \mathrm{~B} 1$ and $3 \mathrm{~A} 1$ in the $\mathrm{SC} 58125$ treated group there was a nonsignificant tendency for increase (CYP 2B1: Fig. 4A, CYP 3A1: Fig. 4B) with concentration dependence (CYP 2B1: Fig. 5A, CYP 3A1: Fig. 5B). These results indicate that the effect of SC58125 is dose dependent manner in the liver. In the phenobarbital treated group the increase was significant. With regard to PCNA, only the SC58125 $5 \mathrm{ppm}$ treated group demonstrated significant elevation (Fig. 4C).

\section{Discussion}

Our expectation in this study was that GST-P positive foci would be inhibited by all of the COX inhibitors. In fact 
Table 3. Expression Levels of mRNAs vs. Control Group by Microarray Analysis (Experiment 2)

\begin{tabular}{|c|c|c|c|}
\hline & $\begin{array}{l}\text { SC58125 } \\
10 \mathrm{ppm}\end{array}$ & $\begin{array}{l}\text { Indomethacin } \\
10 \mathrm{ppm}\end{array}$ & $\begin{array}{l}\text { Phenobarbital } \\
500 \mathrm{ppm}\end{array}$ \\
\hline actin beta $\left(\mathrm{IC}^{1}\right)$ & $1.15^{*}$ & 2.34 & 0.85 \\
\hline cyclophilin (IC) & 1.43 & 2.42 & 1.1 \\
\hline GAPDH (glyceraldehyde phosphate dehydrogenase) (IC) & 0.91 & 2.18 & 0.96 \\
\hline NADPH (nicotinamide adenine dinucleotide phosphatase) & 1.56 & 2.71 & 1.49 \\
\hline $\mathrm{N}$-acetyltransferase 2 & 2.47 & 3.48 & 0.61 \\
\hline CYP (cytochrome P450) 1A1 & 1.23 & 2.31 & 0.89 \\
\hline CYP1A2 & 1.4 & 2.33 & 0.83 \\
\hline CYP2A1 & 4.62 & 3.47 & 5.08 \\
\hline CYP2B1 & 18.89 & 2.51 & 42.12 \\
\hline CYP2C9 & 2.6 & 2.52 & 2.72 \\
\hline CYP2C11 & 1.75 & 2.3 & 1.16 \\
\hline CYP2D6 & 1.03 & 2.26 & 1.03 \\
\hline CYP2E1 & 1.98 & 2.43 & 1.57 \\
\hline CYP2F1 & 1.29 & 2.14 & 1.02 \\
\hline CYP3A1 & 4.18 & 2.69 & 6.97 \\
\hline CYP3A2 & 4.53 & 2.62 & 8.08 \\
\hline CYP4A1 & 2.03 & 3.2 & 1.55 \\
\hline CYP4B1 & 2.57 & 3.56 & 1.81 \\
\hline GST (glutathione S-transferase) 5-5 & 3.37 & 3.36 & 1.17 \\
\hline GST 7-7 & 0.89 & 1.63 & 0.67 \\
\hline GST M3 & 1.78 & 2.59 & 1.76 \\
\hline GST M5 & 1.87 & 2.64 & 1.78 \\
\hline GST Ya & 1.22 & 2.37 & 1.34 \\
\hline GST Yb2 & 0.91 & 2.24 & 1.22 \\
\hline GST Yc1 & 1.27 & 2.25 & 0.82 \\
\hline PCNA (proliferating cell nuclear antigen) & 0.73 & 1.96 & 0.55 \\
\hline POLYU (polyubiqutin) (IC) & 1.2 & 2.31 & 1.04 \\
\hline LAMD (lambda DNA) $\left(\mathrm{NC}^{2}\right)$ & 2.8 & 4.16 & 3.77 \\
\hline
\end{tabular}

* Ratio to expression level of liver in rats treated with basal diet.

1: internal control.

2: negative control.

NS398, nimesulide and indomethacin did show tendencies to reduce GST-P positive foci, but the results were not statistically significant. Nimesulide, a COX-2 inhibitor, at a dose of 200 ppm, was reported to significantly inhibit GST$\mathrm{P}$ positive foci induced by choline-deficient, L-amino aciddefined diet in F344 male rats $^{8}$. The dose of test chemicals $(10 \mathrm{ppm})$ in our experiment may have been too low to induce chemopreventive potential.

In contrast, a significant increase in GST-P positive foci was noted with SC58125 treatments, along with elevation of the liver weight and expression of drug metabolizing enzymes. The medium-term rat liver bioassay employed in the present study has become widely recognized as a solution overcoming the disadvantages of both in vitro shortterm screening tests and long-term in vivo bioassays ${ }^{27}$, and compounds that reduce GST-P positive foci development in this assay are generally regarded as effective for chemoprevention ${ }^{17}$. In contrast, it has been demonstrated that chemicals which give positive results in this assay act as hepatocarcinogens or hepatopromoting agents in the long term $^{28,29}$. Thus, the present results suggest that SC58125 may be a long-term hepatocarcinogen or hepatopromoting agent.
In our study, SC58125 increased the liver weights significantly. Histopathologically, this was observed to be due to the swelling of liver cells, not their proliferation. Expression of PCNA is associated with carcinogenesis ${ }^{30}$ but its mRNA level with SC58125 at 10 ppm was unchanged, despite the significant increase in both number and size of GST-P positive foci. Immunostaining of PCNA also showed no variation in positive cells between SC58125 treated and control rat livers (data not shown). From these data, the promoting potential by SC58125 is not due to cell proliferation. Expression levels of mRNAs of CYPs 2B1 and 3A1 increased dose dependently, and thus, it seems that they the major mechanism of liver weight increase induced by SC 58125 .

Regarding mechanisms of action, the hepatocyte findings histopathologically (Fig. 3A, 3B) showed some similarities with phenobarbital treatment ${ }^{31}$, indicating the role of CYP drug-metabolizing enzymes. Indeed, the results of the microarray analysis in Experiment 2 demonstrated that similar types of CYPs induced by phenobarbital ${ }^{32}$ were also increased by SC58125. We should take note of the similarity of the mRNA expression pattern induced by SC58125 to that of phenobarbital. It indicates that the effect on the liver of 
A

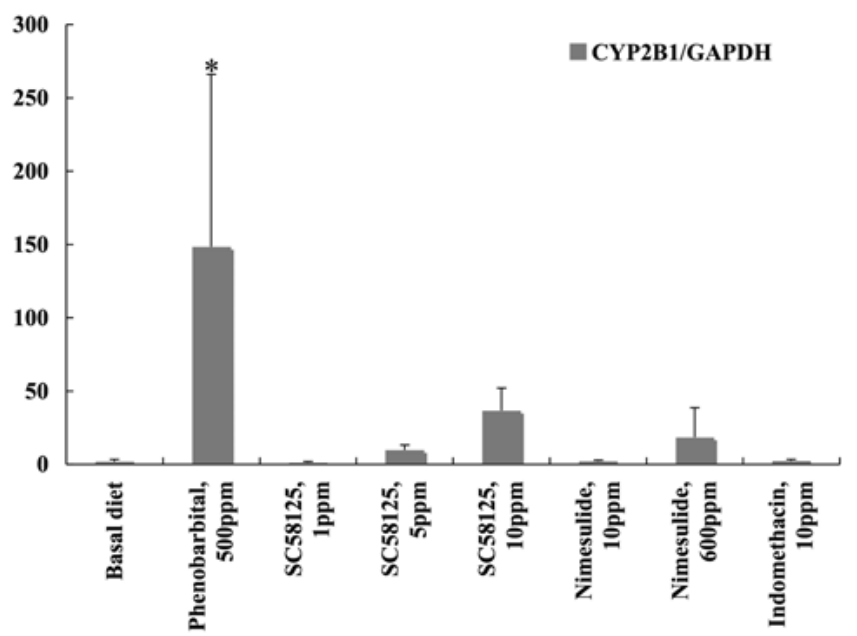

C

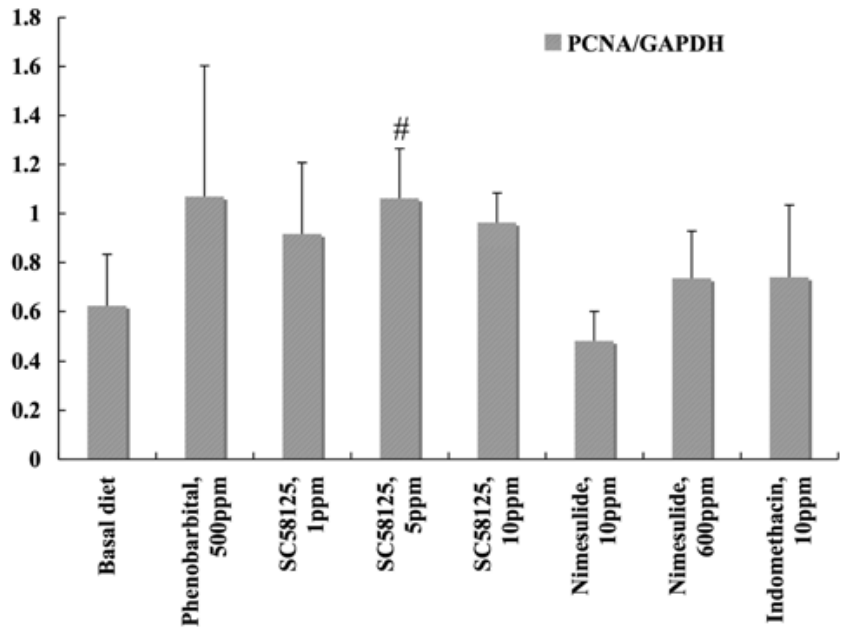

B

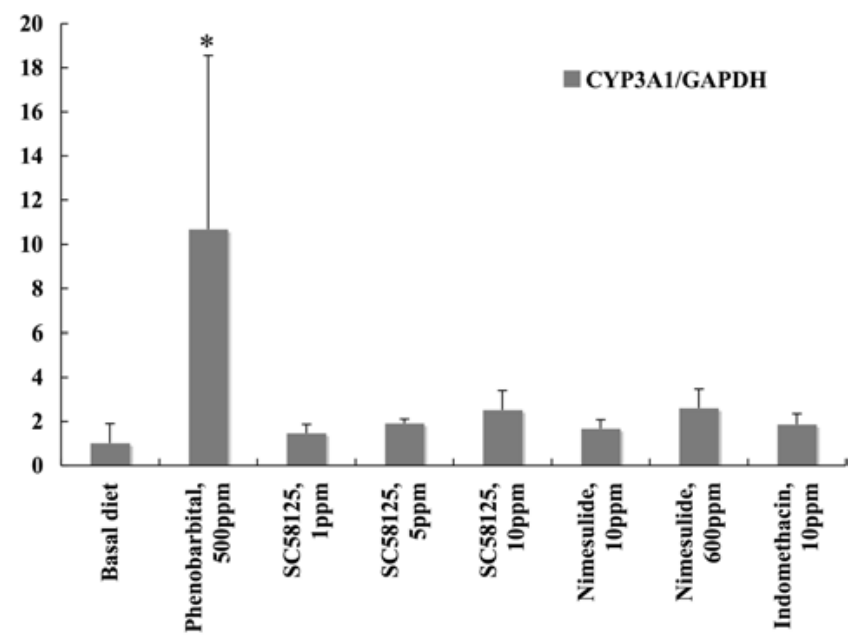

Fig. 4. 4A: Expression levels of mRNA of CYP 2B1 in the livers of rats treated with test chemicals in Experiment 2. $\mathrm{P}<0.05$ vs. basal diet treated group. 4B: Expression levels of mRNA of CYP 3A1 in the livers of rats treated with test chemicals in Experiment 2. $\mathrm{P}<0.05$ vs. basal diet treated group. 4C: Expression levels of mRNA of PCNA in the livers of rats treated with test chemicals in Experiment 2. $\mathrm{P}<0.05$ vs. basal diet, nimesulide $10 \mathrm{ppm}$ or $600 \mathrm{ppm}$ treated groups.
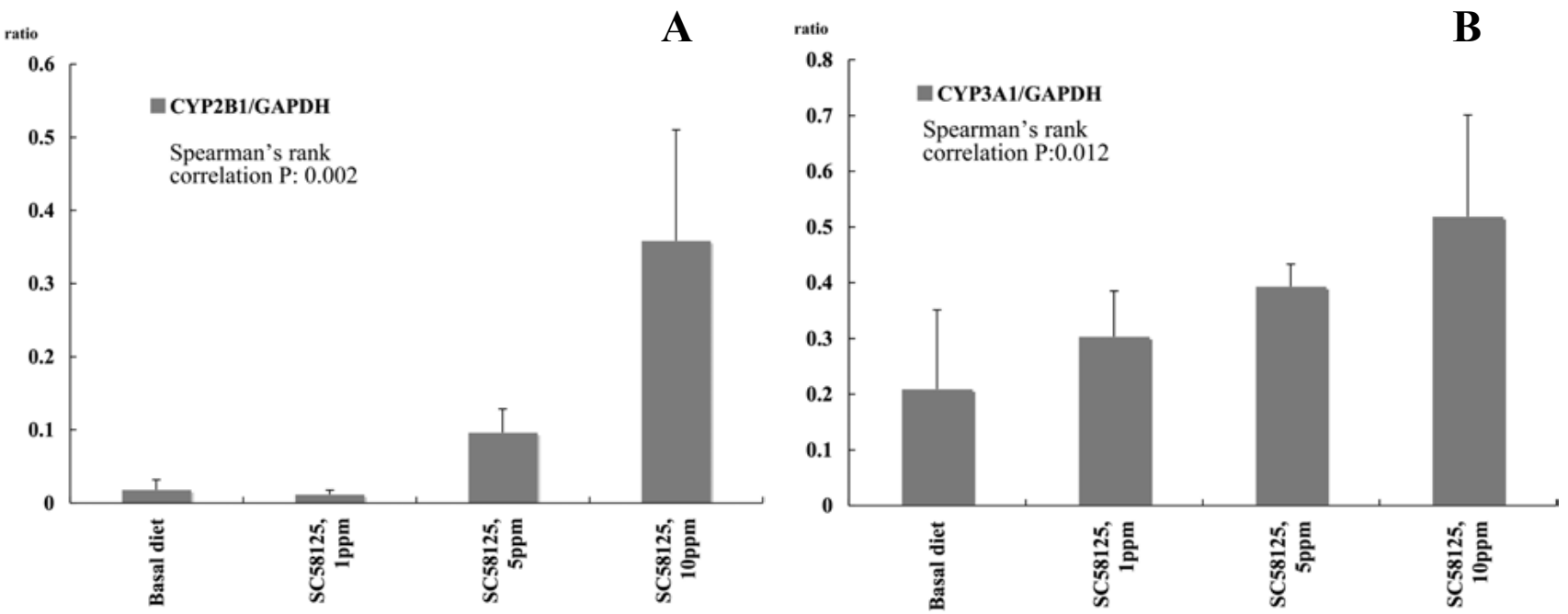

Fig. 5. 5A: Expression levels of mRNA of CYP 2B1 in the livers of rats treated with 0 ppm (basal diet), 1 ppm, 5 ppm and 10 ppm SC58125. With CYP 2B1 in the SC58125 treated group there was a non-significant tendency for dose-dependent increase. 5B: Expression levels of mRNA of CYP 3A1 in the liver of rats treated with 0 ppm (basal diet), 1 ppm, 5 ppm and $10 \mathrm{ppm}$ SC58125. With CYP 2B1 in the SC58125 treated group there was a non-significant tendency for dose-dependent increase. 
SC58125 may be due to a mechanism similar to that of phenobarbital. Phenobarbital is a hepatocarcinogenic chemical, accordingly the hepatocarcinogenic potential of SC58125 also requires attention.

Expression levels of mRNAs of CYPs $2 \mathrm{~B} 1$ and $3 \mathrm{~A} 1$, examined by quantitative real time RT-PCR, also exhibited dose dependent increases. CYP 2C9 plays a key role in the metabolism of non steroidal anti-inflammatory drugs (NSAIDs) $^{33,34}$. Induction of CYP $2 \mathrm{~B} 1$ and $3 \mathrm{~A} 1$ in our experiments was not connected with metabolic regulation of SC58125. Rat CYP 2B1 and 3A1 catalyze $16 \beta$ - and $6 \beta$ testosterone hydroxylase $\mathrm{e}^{35,36}$ and resultant testosterone increase might promote GST-P expression in the rat liver during hepatocarcinogenesis ${ }^{37,38}$.

In conclusion, one of the COX-2 inhibitors, SC58125, only at a $10 \mathrm{ppm}$ dose was here found to have promotive potential for hepatocarcinogenesis in rats, associated with cell hypertrophy and CYP 2B1 and 3A1 induction, similar to phenobarbital. Although COX-2 selective inhibitors are good candidates for chemoprevention, it will be necessary to carefully examine for any adverse toxic effects at the whole body level before clinical application can be recommended.

\section{References}

1. Giovannucci E, Egan KM, Hunter DJ, Stampfer MJ, Colditz GA, Willett WC, and Speizer FE. Aspirin and the risk of colorectal cancer in women. N Engl J Med. 333: 609-614. 1995.

2. Giardiello FM, Hamilton SR, Krush AJ, Piantadosi S, Hylind LM, Celano P, Booker SV, Robinson CR, and Offerhaus GJ. Treatment of colonic and rectal adenomas with sulindac in familial adenomatous polyposis. N Engl $\mathrm{J}$ Med. 328: 1313-1316. 1993.

3. Dubois RN, Abramson SB, Crofford L, Gupta RA, Simon LS, Van De Putte LB, and Lipsky PE. Cyclooxygenase in biology and disease. Faseb J. 12: 1063-1073. 1998.

4. Jones DA, Carlton DP, McIntyre TM, Zimmerman GA, and Prescott SM. Molecular cloning of human prostaglandin endoperoxide synthase type II and demonstration of expression in response to cytokines. J Biol Chem. 268: 9049-9054. 1993.

5. Pairet $\mathrm{M}$ and Engelhardt G. Distinct isoforms (COX-1 and COX-2) of cyclooxygenase: possible physiological and therapeutic implications. Fundam Clin Pharmacol. 10: 1-17. 1996.

6. Taketo MM. Cyclooxygenase-2 inhibitors in tumorigenesis (Part II). J Natl Cancer Inst. 90: 1609-1620. 1998.

7. Taketo MM. Cyclooxygenase-2 inhibitors in tumorigenesis (part I). J Natl Cancer Inst. 90: 1529-1536. 1998.

8. Denda A, Kitayama W, Murata A, Kishida H, Sasaki Y, Kusuoka O, Tsujiuchi T, Tsutsumi M, Nakae D, Takagi H, and Konishi Y. Increased expression of cyclooxygenase-2 protein during rat hepatocarcinogenesis caused by a cholinedeficient, L-amino acid-defined diet and chemopreventive efficacy of a specific inhibitor, nimesulide. Carcinogenesis. 23: 245-256. 2002.

9. Shiotani H, Denda A, Yamamoto K, Kitayama W, Endoh T, Sasaki Y, Tsutsumi N, Sugimura M, and Konishi Y. Increased expression of cyclooxygenase-2 protein in 4- nitroquinoline-1-oxide-induced rat tongue carcinomas and chemopreventive efficacy of a specific inhibitor, nimesulide. Cancer Res. 61: 1451-1456. 2001.

10. Tatematsu M, Hasegawa R, Imaida $K$, Tsuda $H$, and Ito $N$. Survey of various chemicals for initiating and promoting activities in a short-term in vivo system based on generation of hyperplastic liver nodules in rats. Carcinogenesis. 4: 381386. 1983.

11. Hasegawa R, Futakuchi M, Mizoguchi Y, Yamaguchi T, Shirai T, Ito N, and Lijinsky W. Studies of initiation and promotion of carcinogenesis by $\mathrm{N}$-nitroso compounds. Cancer Lett. 123: 185-191. 1998.

12. Ito $\mathrm{N}$, Tatematsu $\mathrm{M}$, Nakanishi $\mathrm{K}$, Hasegawa $\mathrm{R}$, Takano $\mathrm{T}$, Imaida $\mathrm{K}$, and Ogiso $\mathrm{T}$. The effects of various chemicals on the development of hyperplastic liver nodules in hepatectomized rats treated with $\mathrm{N}$-nitrosodiethylamine or N-2-fluorenylacetamide. Gann. 71: 832-842. 1980.

13. Sakai $H$, Tsukamoto $T$, Yamamoto $M$, Shirai N, Iidaka $T$, Yanai T, Masegi T, and Tatematsu M. Differential effects of partial hepatectomy and carbon tetrachloride administration on induction of liver cell foci in a model for detection of initiation activity. Jpn J Cancer Res. 92: 1018-1025. 2001.

14. Tsuda H, Lee G, and Farber E. Induction of resistant hepatocytes as a new principle for a possible short-term in vivo test for carcinogens. Cancer Res. 40: 1157-1164. 1980.

15. Ito N, Tsuda H, Tatematsu M, Inoue $\mathrm{T}$, Tagawa $\mathrm{Y}$, Aoki $\mathrm{T}$, Uwagawa S, Kagawa M, Ogiso T, Masui T, Imaida K, Fukushima S, and Asamoto M. Enhancing effect of various hepatocarcinogens on induction of preneoplastic glutathione S-transferase placental form positive foci in rats-an approach for a new medium-term bioassay system. Carcinogenesis. 9: 387-394. 1988.

16. Ito $\mathrm{N}$, Hasegawa $\mathrm{R}$, Imaida $\mathrm{K}$, Hirose $\mathrm{M}$, and Shirai $\mathrm{T}$. Medium-term liver and multi-organ carcinogenesis bioassays for carcinogens and chemopreventive agents. Exp Toxicol Pathol. 48: 113-119. 1996.

17. Ito N, Imaida $\mathrm{K}$, Asamoto M, and Shirai T. Early detection of carcinogenic substances and modifiers in rats. Mutat Res. 462: 209-217. 2000.

18. Shirai T. A medium-term rat liver bioassay as a rapid in vivo test for carcinogenic potential: a historical review of model development and summary of results from 291 tests. Toxicol Pathol. 25: 453-460. 1997.

19. Kitano M, Ichihara T, Matsuda T, Wanibuchi H, Tamano S, Hagiwara A, Imaoka S, Funae Y, Shirai T, and Fukushima S. Presence of a threshold for promoting effects of phenobarbital on diethylnitrosamine-induced hepatic foci in the rat. Carcinogenesis. 19: 1475-1480. 1998.

20. Watanabe T, Katsura Y, and Yoshitake A. Image processors for analytical pathology. J Toxicol Pathol. 7: 353-361. 1994.

21. Hokaiwado N, Asamoto M, Tsujimura K, Hirota T, Ichihara $\mathrm{T}$, Satoh T, and Shirai T. Rapid analysis of gene expression changes caused by liver carcinogens and chemopreventive agents using a newly developed three-dimensional microarray system. Cancer Science. 95: 123-130. 2003.

22. Burczynski ME, McMillian M, Parker JB, Bryant S, Leone A, Grant ER, Thorne JM, Zhong Z, Zivin RA, and Johnson MD. Cytochrome P450 induction in rat hepatocytes assessed by quantitative real-time reverse-transcription polymerase chain reaction and the RNA invasive cleavage assay. Drug Metab Dispos. 29: 1243-1250. 2001.

23. Kodavanti PR, Kodavanti UP, Faroon OM, and Mehendale 
HM. Pivotal role of hepatocellular regeneration in the ultimate hepatotoxicity of $\mathrm{CCl} 4$ in chlordecone-, mirex-, or phenobarbital-pretreated rats. Toxicol Pathol. 20: 556-569. 1992.

24. Schilter B, Andersen MR, Acharya C, and Omiecinski CJ. Activation of cytochrome P450 gene expression in the rat brain by phenobarbital-like inducers. J Pharmacol Exp Ther. 294: 916-922. 2000.

25. Ganem LG, Trottier E, Anderson A, and Jefcoate CR. Phenobarbital induction of CYP $2 \mathrm{~B} 1 / 2$ in primary hepatocytes: endocrine regulation and evidence for a single pathway for multiple inducers. Toxicol Appl Pharmacol. 155: 32-42. 1999.

26. Sidhu JS and Omiecinski CJ. Protein synthesis inhibitors exhibit a nonspecific effect on phenobarbital-inducible cytochome $\mathrm{P} 450$ gene expression in primary rat hepatocytes. J Biol Chem. 273: 4769-4775. 1998.

27. Ito N, Hasegawa R, Imaida K, Hirose M, and Shirai T. Medium-term rat liver bioassay for rapid detection of hepatocarcinogenic substances. J Toxicol Pathol. 10: 1-11. 1997.

28. Ito N, Hasegawa R, Imaida K, Takahashi S, and Shirai T. Medium-term rat liver bioassay for rapid detection of carcinogens and modifiers of hepatocarcinogenesis. Drug Metab Rev. 26: 431-442. 1994.

29. Ogiso T, Tatematsu M, Tamano S, Hasegawa R, and Ito N. Correlation between medium-term liver bioassay system data and results of long-term testing in rats. Carcinogenesis. 11: 561-566. 1990.

30. Eldrige SR, Butterworth BE, and Goldsworthy TL. Proliferating cell nuclear antigen: a marker for hepatocellular proliferation in rodents. Environ Health Perspect. 101(Suppl 5): 211-218. 1993.

31. Grossman HJ, Grossman VL, and Bhathal PS. The effect of hepatocyte enlargement on the hemodynamic characteristics of the isolated perfused rat liver preparation. Hepatology. 27: 446-451. 1998.

32. Hartley DP and Klaassen CD. Detection of chemicalinduced differential expression of rat hepatic cytochrome P450 mRNA transcripts using branched DNA signal amplification technology. Drug Metab Dispos. 28: 608-616. 2000.

33. Visser LE, van Schaik RH, van Vliet M, Trienekens PH, De Smet PA, Vulto AG, Hofman A, van Duijn CM, and Stricker $\mathrm{BH}$. Allelic variants of cytochrome P450 2C9 modify the interaction between nonsteroidal anti-inflammatory drugs and coumarin anticoagulants. Clin Pharmacol Ther. 77: 479485. 2005.

34. Guo Y, Zhang Y, Wang Y, Chen X, Si D, Zhong D, Fawcett JP, and Zhou H. Role of CYP2C9 and its variants (CYP2C $9 * 3$ and CYP2C9*13) in the metabolism of lornoxicam in humans. Drug Metab Dispos. 33: 749-753. 2005.

35. Waxman DJ. Growth hormone pulse-activated STAT5 signalling: a unique regulatory mechanism governing sexual dimorphism of liver gene expression. Novartis Found Symp. 227: 61-74; discussion 75-81. 2000.

36. Fan LQ, You L, Brown-Borg H, Brown S, Edwards RJ, and Corton JC. Regulation of phase I and phase II steroid metabolism enzymes by PPAR alpha activators. Toxicology. 204: 109-121. 2004.

37. Liu F, Chen HL, Shimizu I, and Ito S. [Effects of sex hormones on the expression of placenta form glutathione Stransferase (GST-P) in rat induced hepatocarcinoma]. Shi Yan Sheng Wu Xue Bao. 31: 393-401. 1998.

38. Shimizu I, Yasuda M, Mizobuchi Y, Ma YR, Liu F, Shiba $\mathrm{M}$, Horie T, and Ito S. Suppressive effect of oestradiol on chemical hepatocarcinogenesis in rats. Gut. 42: 112-119. 1998. 